\title{
加工硬化を考慮した円筒の軸圧潰における平均荷重の評価*
}

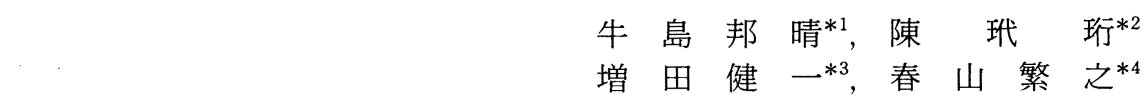

\section{Evaluation of Average Load in Axial Crushing of Circular Tubes in Consideration of Strain Hardening Effect}

\author{
Kuniharu USHIJIMA*5, Dai-Heng CHEN, \\ Kenichi MASUDA and Shigeyuki HARUYAMA \\ ${ }^{* 5}$ Department of Mechanical Engineering, Faculty of Engineering, Kyushu Sangyo University, \\ 2-3-1 Matsukadai, Higashi-ku, Fukuoka-shi, Fukuoka, 813-8503 Japan
}

In this paper, elastoplastic crushing behavior of circular tubes under axial compressive loading is studied by using nonlinear finite element analysis software MSC.Marc. In particular, effects of strain hardening on the average crushing load $P_{\text {ave }}$ in axial collapse are investigated. It is found that the average load $P_{\text {ave }}$ depends on the scale of strain-hardening, and the theoretical result of $P_{\text {ave }}$ for rigid perfectly plastic material cannot be used to, evaluate the load $P_{\text {ave }}$ with strain-hardening material. So in order to take into consideration the strain hardening effect on the average load $P_{\text {ave }}$, we propose an energy equivalent flow stress $\sigma_{\text {flow }}$ defined by the value of average effective plastic strain $\bar{\varepsilon}_{p, e q}$ which arises in one folded wrinkle, and evaluate the average load $P_{\text {ave }}$ by using $\sigma_{\text {flow }}$ instead of yield stress $\sigma_{y}$. This approximate evaluation agrees well with the experimental result.

Key Words: Plasticity, Buckling, FEM, Finite Deformation Theory, Circular Tubes, Axial Collapse

\section{1. 鍺言}

近年, 地球環境保護の観点から自動車の軽量化要求 が強くなる一方で, 衝突事故を引き起こした際に乗員 の安全性を確保するため, 衝撃エネルギーを吸収する 部材として車両前方部にアルミニウム合金製の薄肉円 筒や角筒が広く用いられている．例えば，図 1 は円筒 を軸方向に圧潰させたときの, 圧縮荷重 $P_{x}$ と軸方向 変位 $U_{x}$ との関係を模式的に示したものである．軸圧 潰過程において，円筒端部の拘束による局所的な曲げ に対応して圧縮荷重のピーク $P_{p e a k}$ が現れ，その後円 筒内に生じる新たなしわの生成と折り畳みに対応し, 圧縮荷重 $P_{x}$ の周期的な変動が見られる. 従ってこう した薄肉部材のエネルギー吸収特性を評価するため, 吸収特性を表すパラメータであるピーク荷重 $P_{p e a k}$ や 平均荷重 $P_{\text {ave }}$ を正確に求める必要がある.

そうした薄肉部材の静的・動的圧潰特性について, Alexander ${ }^{(1)}$ をはじめこれまで数多くの理論的, 実験的

* 原稿受付 2005 年 12 月 5 日.

*1 正員, 九州産業大学工学部機械工学科( $\$$ 813-8503 福岡市 東区松香台 2-3-1).

*2 正員, 東京理科大学工学部機械工学科(画162-8601 東京都 新宿区神楽坂 $1-3$ ).

*3 東京理科大学大学院工学研究科.

*4 正員, 福岡県工業技術センター(画807-0831 北九州市八幡 西区則松 3-6-1)

E-mail : kuniharu@ip.kyusan-u.ac.jp

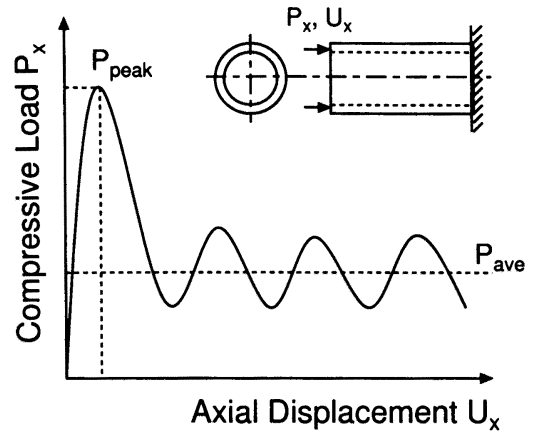

Fig. 1 Typical Compressive Load - Axial Displacement Curve for a Circular Tube

ならびに数值解析による研究が行われてきた (1) (18). 例えばAlexander ${ }^{(1)}$ は, 剛完全塑性体と仮定した薄肉円 筒を軸方向へ準静的に圧潰させた時の, 円筒が軸対称 に変形する理論モデルを提案し, 円筒に生じるしわが 一つずつ折り畳まれる過程において, 平均荷重による 外部仕事としわ生成で生じる膨張と曲げによる内部消 費エネルギーとのつりあい条件により, 平均荷重 $P_{\text {ave }}$ の理論解を求めている. また, Alexander ${ }^{(1)} の$ 理論モデ ルを用い, より実際の変形に対応するよう, 理論モデ ルの改良が多くの研究者によって行われた (2),(3),(16). 
例えばAbramowicz ら ${ }^{(2)}$ は, 実際の変形において, しわ は直線的ではなく一定の曲率を持った曲線形状を持っ て折り重なることを考慮し, 有効圧潰距離 $\delta_{e}$ を用い た理論モデルを提案している．また，Wierzbicki ら ${ }^{(3)}$ は圧潰過程で塑性ヒンジ点が移動しながら複数のしわ が連続的に折り畳まれる変形モデルを提案して, 平均 荷重 $P_{a v e}$ の理論解を求めている.

一方著者ら ${ }^{(4)}$ もれまで, 加工硬化をもつ薄肉円筒 の軸圧潰特性に対し, 有限要素法による弾塑性数值シ ミュレーション解析に基づく検討を行ってきた. 著者 らはまず円筒に生じる初期ピーク荷重 $P_{\text {peak }}$ に注目し， このピーク值に及ぼす円筒の幾何形状や加工硬化特性 の影響を調べ, 解析結果に基づいて円筒の形状と材料 の応力ーひずみ関係から, ピーク荷重 $P_{\text {peak }}$ を精度よ く評価する近似手法を提案した.

これまで多くの研究者 ${ }^{(1)}$ (3) により提案された円筒 の軸圧潰における平均荷重の理論解には, 材料の影響 として降伏応力のみが含まれており, 塑性降伏後の加 工硬化を考慮してより精度よく評価するためには, 理 論解中の降伏応力の代わりに圧潰過程で吸収したエネ ルギー量に等価な流れ応力を用いる必要がある. Galib ら ${ }^{(5)}$ はアルミニウム合金（A6060-T5）製薄肉円筒（直 径 $D=58[\mathrm{~mm}]$, 肉厚 $t=2[\mathrm{~mm}]$, 長さ $L=200[\mathrm{~mm}]$ ）の動 的軸圧潰実験を行い, 材料の $0.2 \%$ 耐力 $\sigma_{0.2}$ と引張り 強さ $\sigma_{u}$ の平均值として流れ応力を定義し, 実験で得た 平均荷重の評価を行っている. しかしながら, Galibら の検討 ${ }^{(5)}$ は 1 種類の円筒のみにとどまっており, 種々 の幾何形状や加工硬化特性を持つ円筒に対しては検討 しておらず，加工硬化を考慮した平均荷重の評価法に ついて, より詳細な検討が必要であるといえる.

そこで本研究では, 円筒の軸方向圧潰特性について, 有限要素法による弾塑性数值シミュレーション解析を 行い, 円筒の幾何形状や加工硬化特性を変化させなが ら平均荷重 $P_{\text {ave }}$ を求め, 加工硬化を考慮した平均荷重 $P_{\text {ave }}$ に対し, 近似評価法の提案を試みる.

\section{2. 解 析 方 法}

図 2 に本研究で用いた解析モデルの概要を示す. 本 研究では有限要素法汎用ソフトMSC.Marc を用いた弾 塑性大変形数值シミュレーション解析を行った. 図中 に示すように, 本研究では円筒の幾何形状を表すパラ メータとして, 肉厚 $t$, 半径 $R$, 全長 $L$ を用いる. 円 筒が非常に長い場合, 軸圧潰過程で円筒が長柱型の座 屈を生じ，エネルギー吸収特性が著しく低下寸ること がある ${ }^{(17)}$. 本研究では軸圧潰過程において, 長柱型の 座屈が生じることなく安定した変形モードが得られる
よう, 全長 $L=150[\mathrm{~mm}]$ と固定して解析を行った.

次に境界条件として, 図 2 中に示すように, 円筒下 端を剛体面に固定し，上端側より別の剛体を軸方向（ $x$ 方向）へ移動させながら円筒を圧潰させる.このよう に円筒端部を剛体に拘束することで, 軸圧潰時に局所 的なしわが端部より次々と生じる. 本研究では, 上下 剛体面と円筒の端部，ならびに円筒同士の接触部にお ける摩擦の影響は無視し, 円筒を半分の長さ $L / 2$ まで 圧潰させたときの軸方向荷重 $P_{x}$ の平均値を平均荷重 $P_{\text {ave }}$

$$
P_{\text {ave }}=\frac{2}{L} \int_{0}^{L / 2} P_{x} \mathrm{~d} U_{x}
$$

と定義する. 以下ではこの $P_{\text {ave }}$ に対する円筒幾何形状 （肉厚 $t$, 半径 $R$ ） や加工硬化特性の影響について検討 する.

また, 本研究では解析対象の円筒を等方・均質な弾 塑性材料と仮定し, 塑性降伏後の材料の応力ーひずみ 関係は, 以下に示す 2 種類の加工硬化則を用いる. ま ず第一の硬化則として, 塑性域 $\left(\sigma>\sigma_{y}, \sigma_{y}\right.$ は降伏応力 を表す) における応力勾配 $\partial \sigma / \partial \varepsilon$ が一定な二直線硬 化則

$$
\sigma=\sigma_{y}+E_{h}\left(\varepsilon-\frac{\sigma_{y}}{E}\right)=\sigma_{y}+\frac{1}{\left(1 / E_{h}-1 / E\right)} \varepsilon_{p}
$$

を用いる（ただし, 式中の $E$ は縦弾性係数, $E_{h}$ は加 工硬化係数, $\varepsilon$ は全ひずみ, $\varepsilon_{p}$ は塑性ひずみを表す). もうひとつの硬化則として, 忘力勾配がひずみととも に連続的に変化する swift 型の $n$ 乗硬化則

$$
\sigma=c\left(a+\varepsilon_{p}\right)^{n}
$$

を用いる(ただし，式中の $a$ と $c$ は加工硬化係数, $n$ は 加工硬化指数, $\varepsilon_{p}$ は塑性ひずみを表す).

さらに, 本研究で行う弾塑性数值シミュレーション 解析において, 塑性降伏条件はミーゼスの降伏条件, 非線形変形挙動の定式化はアップデーテッドラグラン ジュ法, 非線形方程式の解法はニュートンラプソン法 を用いて解析を行っている.

\section{3. 解析結果および検討}

3.1 加工硬化が非常に小さい円筒の軸圧潰特性(こ れまでの理諭結果との比較）緒言にも述べたよう に, 軸方向圧縮荷重を受ける円筒の圧潰特性について, 材料を剛完全塑性体とみなした理論的研究がこれまで 数多く行われ, 平均荷重 $P_{\text {ave }}$ に関する理論解が提案さ れている. 例えば Alexander ${ }^{(1)}$ は, 円筒の軸圧潰変形 過程において, 図 $3(a)$ に示すような一定の長さ $\lambda$ を もつしわが円筒の外側ないし内側に 1 つずつ折り重な る軸対称変形モデルを提案し, 円周方向の膨張による 


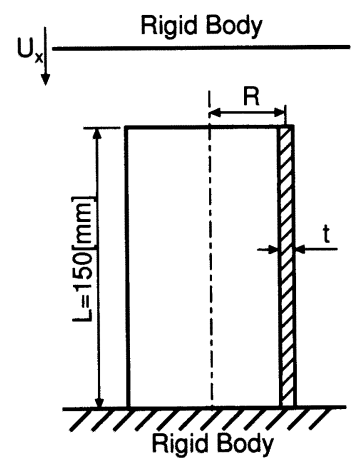

Fig. 2 Tube Geometry and Loading Condition

エネルギーと, 塑性ヒンジ点（図中の A,B,C 点）での 曲げによるエネルギーの総和が, 平均荷重 $P_{\text {ave }}$ による 外部仕事とつり合う条件より, 平均応力 $P_{\text {ave }} /(2 \pi t R)$ について以下の理論解を導出している.

$$
\frac{P_{\text {ave }}}{2 \pi t R}=\frac{4.30 \sigma_{y}}{\pi} \sqrt{\frac{t}{R}}
$$

また, Abramowicz ら ${ }^{(2)}$ は Alexander の変形モデル (1) を改良し，図 3(b) に示すように圧潰過程でしわが一定 の曲率を持って折り畳まれることを考慮し, 有効圧潰 距離 $\delta_{e}$ を導入して Alexander の式を修正した理論解 を導出している.

$$
\frac{P_{\text {ave }}}{2 \pi t R}=\frac{\sigma_{y}}{\pi} \cdot \frac{4.24 \sqrt{t / R}+1.72 t / R}{0.86-0.40 \sqrt{t / R}}
$$

さらに Wierzbicki ら ${ }^{(3)}$ は, 図 3(c) に示すように, 圧 潰過程で塑性ヒンジ点が移動しながら複数のしわが 連続的に折り畳まれる変形モデルを提案し, 平均応力 $P_{\text {ave }} /(2 \pi t R)$ について以下の理論解を導出している.

$$
\frac{P_{\text {ave }}}{2 \pi t R}=\frac{5.61 \sigma_{y}}{\pi} \sqrt{\frac{t}{R}}
$$

本研究ではまず加工硬化が非常に小さい材料につい て解析を行い, 本解析結果と式 (4), (5), (6)に示した 理論結果との比較を行う.

図 4 は加工硬化が非常に小さい $E_{h} / E=1 / 1000$, $1 / 2000,1 / 5000$ をもつ円筒での, 肉厚 $t$ と半径 $R$ の比 $t / R$ (以下では肉厚比と表現）と平均応力 $P_{a v e} /(2 \pi t R)$ との関係を示したものである. 図中には式 (4), (5), (6) の理論結果もそれぞれ実線, 点線, 破線で示している. この図からわかるように, 本解析結果は, 軸圧潰過程 で円筒に生じたしわの曲率を考慮した理論解（式 (5) や式 (6)）に近い值を示しており，加工硬化が小さく

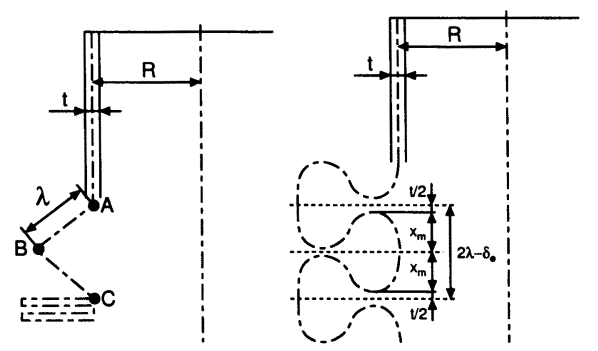

(a)Alexander's model (b) Abramowicz and coworker's model

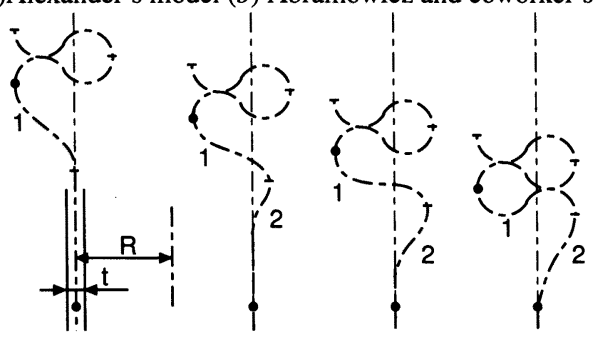

(c)Wierzbicki and coworker's kinematical model

Fig. 3 Deformation Behavior for Circular Tube under Axial Compression

なるほどその差は小さい. またこの結果から, 本解析 の妥当性が確認できたといえる.

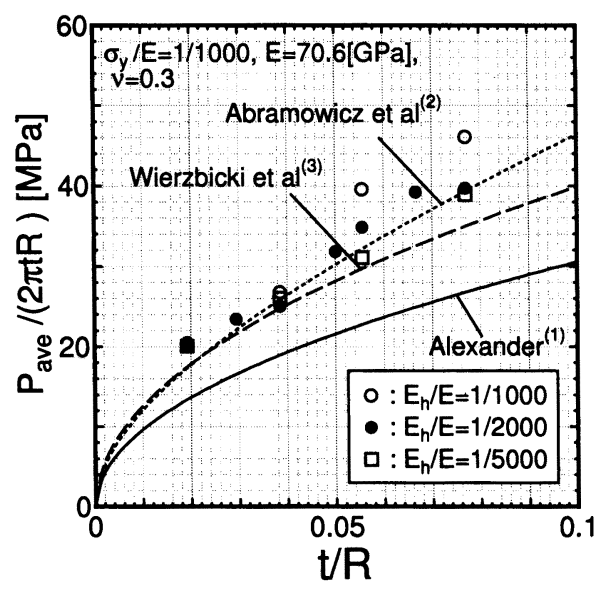

Fig. 4 Relationship between Average Stress $P_{\text {ave }} /(2 \pi t R)$ and Tube Thickness-to-Radius Ratio $t / R$ for Relatively 'Weak' Strain-Hardening Materials

\section{2 加工硬化を考䖒した円筒の軸圧謴特性}

3.2.1 二直線硬化則に従う弾塑性材料の場合 図 5 は塑性降伏以後の材料の応力ーひずみ関係が式 (2)で 
表される二直線硬化則に従うと仮定したときの, 平均 応力 $P_{\text {ave }} /(2 \pi t R)$ と円筒の肉厚比 $t / R$ との関倸を示した ものである. ここで, 3 種類の加工硬化係数 $E_{h}=E / 20$, $E_{h}=E / 100, E_{h}=E / 2000$ での解析結果を, それぞれ ○，○，口印で表している. また, 図6(a),(b)は, 肉厚 比 $t / R=0.06$ の円筒を半分の長さ $L / 2$ まで圧潰させた ときの変形形状を示す. まず図 5 からわかるように, 加 工硬化係数 $E_{h}$ が大きくなるほど平均応力 $P_{\text {ave }} /(2 \pi t R)$ の值は大きくなり, このことからも材料の加工硬化を 考慮した評価法が必要であるといえる，また図 6(a), $(b)$ より, 加工硬化の違いにより円筒に生じる変形形状も 異なり，同じ幾何形状を持つ円筒でも，加工硬化が大 きくなることで軸対称変形から非軸対称変形人と変わ る場合がある.このような円筒に生じる変形モードに 対寸る, 円筒の幾何形状や加工硬化特性, 衝突速度の 影響について著者らはすでに検討を行っており ${ }^{(17)}$, 本 論文では省略する.

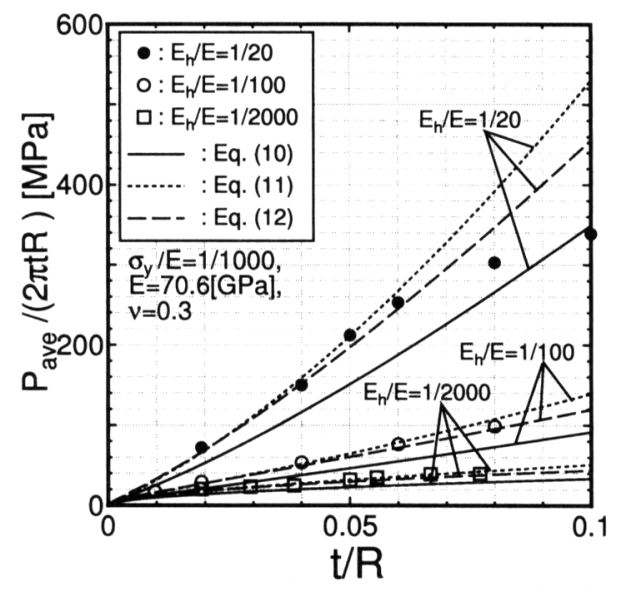

Fig. 5 Relationship between Average Stress $P_{\text {ave }} /(2 \pi t R)$ and Tube Thickness-to-Radius Ratio $t / R$ for Tubes with Hardening Modulus $E_{h}=E / 20, E / 100$ and $E / 2000$

一方，緒言にも述べたように，円筒の軸圧潰におけ る平均応力 $P_{\text {ave }} /(2 \pi t R)$ に対し, 材料の加工硬化を考 慮するためには, 材料物性值として降伏応力 $\sigma_{y}$ の代わ りに，圧潰過程で吸収したエネルギ一量を反映した流 れ応力 $\sigma_{\text {flow }}$ を新たに定義して用いる必要がある。こ の流れ応力 $\sigma_{\text {flow }}$ について, Galib ${ }^{(5)}$ はアルミニウム 合金（A6060-T5）製の薄肉円筒（肉厚 $t=2[\mathrm{~mm}]$, 半 径 $R=29[\mathrm{~mm}]$, 長さ $L=200[\mathrm{~mm}]$ ） の圧潰実験結果 を用い, 流れ応力 $\sigma_{\text {flow }}$ を $0.2 \%$ 耐力 $\sigma_{0.2}$ と引張り強 さ $\sigma_{u}$ の平均值として定義し, それを Abramowiczらの

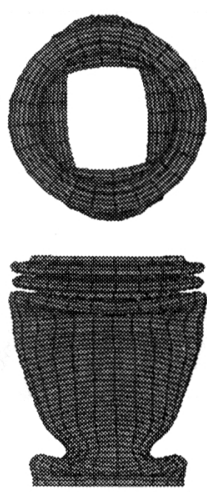

(a) $E_{h}=E / 20$
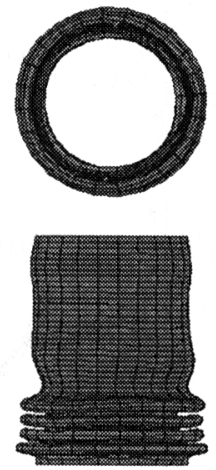

(b) $E_{h}=E / 100$
Fig. 6 Comparison of Deformation Shapes for Tubes of $t / R=0.06$ with Different Hardening Coefficient $E_{h}$

理論解 $^{(1)}$ (式 (5)) 中の降伏応力 $\sigma_{y}$ に置き換え, 実験 で得た平均応力 $P_{\text {ave }} /(2 \pi t R)$ の評価を行っている. し かしながら，Galib ら ${ }^{(5)}$ が検討に用いた円筒は 1 種類 のみにとどまっており, 種々の幾何形状や加工硬化特 性を有する円筒に対し，こうした平均応力の評価の有 効性については，十分に検討されていない，そこで本 研究では, 種々の円筒に対し有限要素法に基づく弾塑 性数值シミュレーション解析を行い, 得られた結果に 基づいて平均応力 $P_{a v e} /(2 \pi t R)$ の評価法を検討した.

図 7 は, 肉厚と半径の比 $t / R=1 / 52$ で加工硬化係 数 $E_{h}=E / 100$ の円筒における, 軸方向の圧縮応力 $P_{x} /(2 \pi t R)$ と無次元化した軸方向変位 $U_{x} / L$ との関係 を示す．図中には，円筒を半分までつぶしたときの平 均応力值 $P_{\text {ave }} /(2 \pi t R)$ を破線で表している. また, 図 中の点'A','B','C'において, 円筒下部近傍に生じた軸 対称型のしわの断面形状を, それぞれ図 $8(a) \sim(c)$ に 示す.これらの図からわかるように, 初期のピーク $P_{\text {peak }} /(2 \pi t R)$ 以降, 圧縮応力の值は円筒を半分まで圧 潰させた時の平均值 $P_{\text {ave }} /(2 \pi t R)$ から, ほぼ一定の割 合で周期的な変動を繰り返し，それぞれのピーク值は， 圧潰過程で円筒の内側と外側に生じるしわの発生と折 り畳みに対応している。

図 9 は，円筒に生じた軸対称型のしわを模式的に表 したものである. 図 8 の結果からもわかるように, 円 筒に生じた軸対称型のしわは, 円筒下端の固定端近傍 を除き,ほぼ一定の形状を持って折り畳まれ, それぞ れのしわにはある曲率を持って大きな曲げ変形が生じ ている部分と, 変形がほとんど生じないで回転してい る部分がある. そこで, 折り畳まれた後の 1 つのしわ 


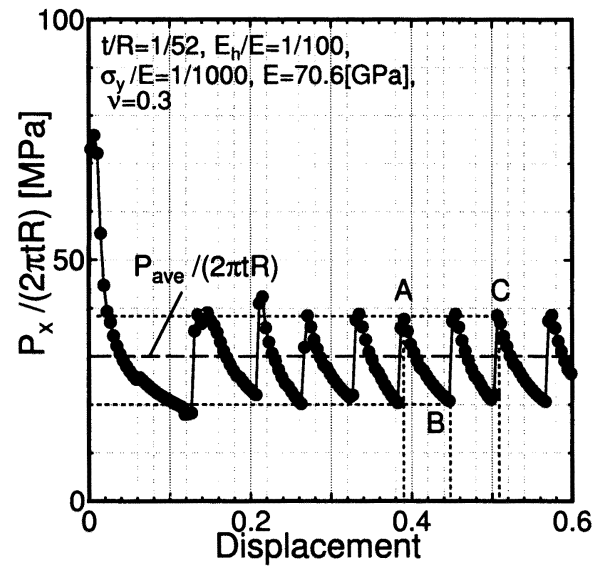

Fig. 7 Relationship between Axial Compressive Stress $P_{x} /(2 \pi t R)$ and Displacement $U_{x} / L$ for a Tube of $t / R=1 / 52$ and $E_{h} / E=1 / 100$

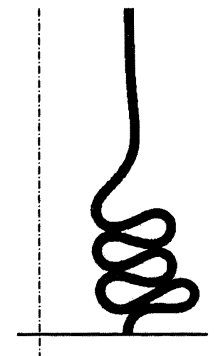

(a) at 'A'

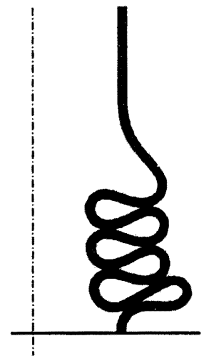

(b)at 'B'

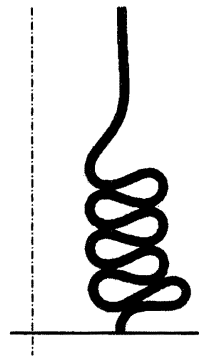

(b)at 'C'
Fig. 8 Deformation Shapes of a Cylindrical Tube at Three Points 'A', 'B' and 'C' Plotted in Fig.7

（図 9 中の経路 1-2-3）に注目し, 図中の経路 1-2-3に 沿って相当塑性ひずみ $\varepsilon_{p, e q}$ 分布の平均をとり，それを $\bar{\varepsilon}_{p, e q}$ とする. この平均值 $\bar{\varepsilon}_{p, e q}$ と円筒の肉厚比 $t / R$ と の関係を図 10 に示す. 図中には種々の加工硬化係数 $E_{h}$ での結果を, 各印で表している. この図からわかる ように, 加工硬化の大小に関わらず, しわ内部に生じ る相当塑性ひずみの平均值 $\bar{\varepsilon}_{p, e q}$ は, 肉厚比 $t / R$ に対 しほぼ一対一に対応する.このことは，円筒に生じる しわの長さが, 加工硬化の違いに関わらず, 円筒の肉 厚 $t$ と半径 $R$ の関数で整理できるという, 先の研究結 果 ${ }^{(7)}$ からも容易に理解できる. 本研究では図 10 に示 した解析結果に基づき， $\bar{\varepsilon}_{p, e q}$ を以下の式で近似する.

$$
\bar{\varepsilon}_{p, e q}=\frac{5}{2}\left(\frac{t}{R}\right)^{4 / 5}
$$

この平均化した相当塑性ひずみ $\bar{\varepsilon}_{p, e q}$ を用い, 本研

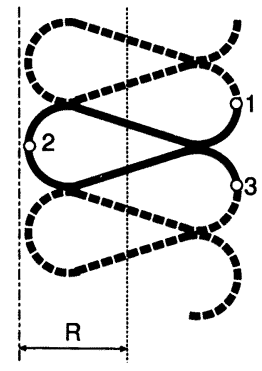

Fig. 9 Idealized Shape of Folded Wrinkles

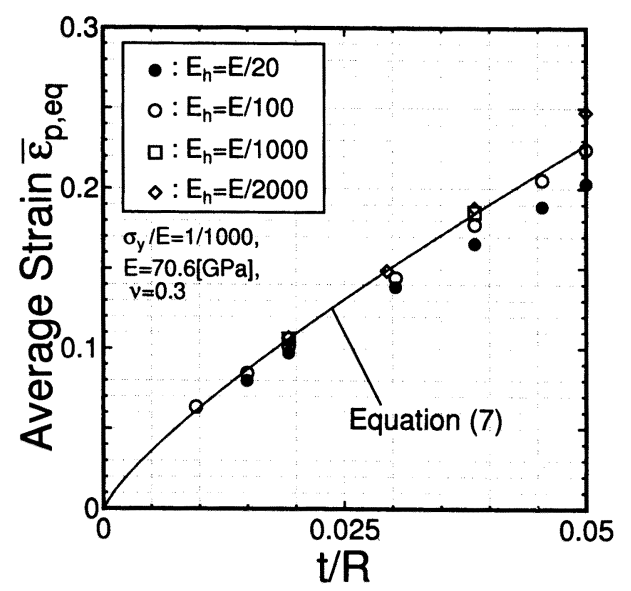

Fig. 10 Relationship between the Average Effective Plastic Strain $\bar{\varepsilon}_{p, e q}$ and Tube Thickness-toRadius Ratio $t / R$

究では流れ忘力 $\sigma_{\text {flow }}$ を以下の式で定義する.

$$
\sigma_{\text {flow }}=\frac{\int_{0}^{\bar{\varepsilon}_{p, e q}} \sigma \mathrm{d} \varepsilon_{p}}{\bar{\varepsilon}_{p, e q}}
$$

式 (2) の二直線硬化則に従う材料の場合, 流れ応力 $\sigma_{\text {flow }}$ は以下の式で表される.

$$
\sigma_{\text {flow }}=\sigma_{y}+\frac{1}{2} \cdot \frac{E E_{h}}{\left(E-E_{h}\right)} \bar{\varepsilon}_{p, e q}
$$

この $\sigma_{\text {flow }}$ を用い，これまで提案された剛完全塑性体 での理論解 (式 (4), 式 (5), 式 (6)) 中の降伏応力 $\sigma_{y}$ に 置き換え, 新たに加工硬化を考慮した平均荷重の近似 式とする. すなわち,

$$
\begin{gathered}
\frac{P_{\text {ave }}}{2 \pi t R}=\frac{4.30 \sigma_{\text {flow }}}{\pi} \sqrt{\frac{t}{R}} \\
\frac{P_{\text {ave }}}{2 \pi t R}=\frac{\sigma_{\text {flow }}}{\pi} \cdot \frac{4.24 \sqrt{t / R}+1.72 t / R}{0.86-0.40 \sqrt{t / R}}
\end{gathered}
$$




$$
\frac{P_{\text {ave }}}{2 \pi t R}=\frac{5.61 \sigma_{\text {flow }}}{\pi} \sqrt{\frac{t}{R}}
$$

を近似評価式として提案する. 図 5 中に近似式 (10), (11)，(12)による結果もそれぞれ実線，点線，破線で 示している.この図からわかるように，加工硬化が小 さい場合と同様，円筒に生じるしわの曲率を考慮した 近似式 (11)，(12)による結果は, 加工硬化倸数 $E_{h}$ の 大小に関わらず, 種々の肉厚比 $t / R$ を有する円筒での 平均応力 $P_{\text {ave }} /(2 \pi t R)$ の解析結果とよく一致している. なお，加工硬化が大きい場合（ $E_{h}=E / 20 ）$ において, 肉厚比 $t / R$ の大きい範囲で解析結果と近似結果との間 に大きな差が見られるのは, 円筒内に生じた非軸対称 変形による影響と考えられる.

3.2.2 $n$ 乗硬化則に従う弾塑性材料の場合 前節 では, 塑性降伏後の応力ーひずみ関係が，式 (2)で表 される二直線硬化則に従う場合における, 円筒の平均 态力の評価について検討を行った．本節ではより一般 的な材料として, 式 (3) に示す swift 型の $n$ 乗硬化則 に従う円筒の問題を考える.

図 11 は, アルミニウム合金 (6063-T7) 材料の応力ー ひずみ関係を式 (3) の $n$ 乗硬化則で示したものである. この応力ーひずみ関係に従う円筒の軸圧潰問題につい て, FEM 解析を行って求めた平均応力 $P_{\text {ave }} /(2 \pi t R)$ と 肉厚比 $t / R$ との関係を図 12 に示す. 式 (3) の $n$ 乗硬化 則に従う材料の場合, 式 (8) で定義した流れ応力 $\sigma_{\text {flow }}$ は以下の式で表される.

$$
\sigma_{\text {flow }}=\frac{\sigma_{y}}{n+1}\left\{\left(1+\frac{\bar{\varepsilon}_{p, e q}}{a}\right)^{n}\left(1+\frac{a}{\bar{\varepsilon}_{p, e q}}\right)-\frac{a}{\bar{\varepsilon}_{p, e q}}\right\}
$$

図 12 中には近似式 (10)，(11)，(12)による結果をそれ ぞれ実線，点線，破線で示す．また，Galibらの近似手 法 ${ }^{(5)}$ を用い, 流れ応力 $\sigma_{\text {flow }}$ を材料の降伏応力 $\sigma_{y}$ と引 張り強さ $\sigma_{u}$ の平均值で表し，(11) 式に代入して求め た近似結果を一点破線で示している.この図からわか るように，态力勾配が連続的に変化する $n$ 乗硬化則に おいても，二直線硬化則の場合と同様，しわの曲率を 考慮した近似結果（式 (11), (12)）は, 肉厚比 $t / R$ の 大小に関わらず，数值解析結果とよく一致している.

以上の結果から，円筒の軸圧潰時における平均応力 $P_{\text {ave }} /(2 \pi t R)$ に対し，材料の加工硬化の影響を考慮す るためには, これまで提案された剛完全塑性体での理 論解 (1) (3) 中の降伏応力 $\sigma_{y}$ の代わりに, 1 つのしわ 内部に生じる相当塑性ひずみの平均值 $\bar{\varepsilon}_{p, e q}$ で定義し た流れ応力 $\sigma_{\text {flow }}$ を用い，これまで提案された剛完全 塑性体での理論解中の降伏応力 $\sigma_{y}$ に置き換えること で, 種々の応力ーひずみ関係をもつ材料に対し，近似 的に評価可能であるといえる.

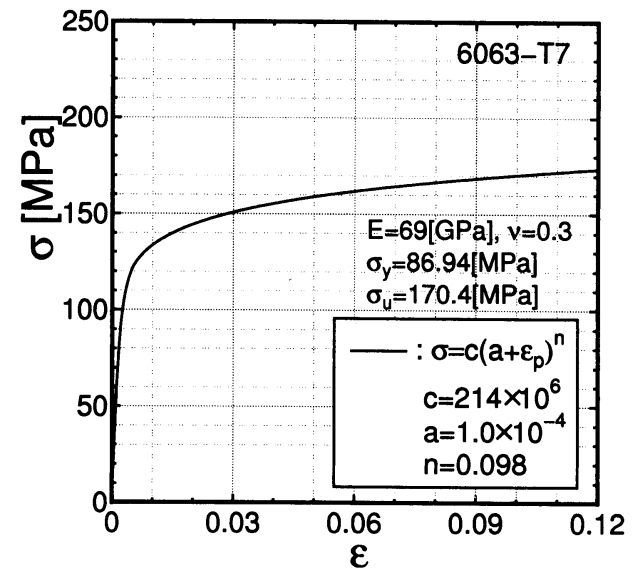

Fig. 11 True Stress and Strain Curve for Aluminium Alloy 6063-T7

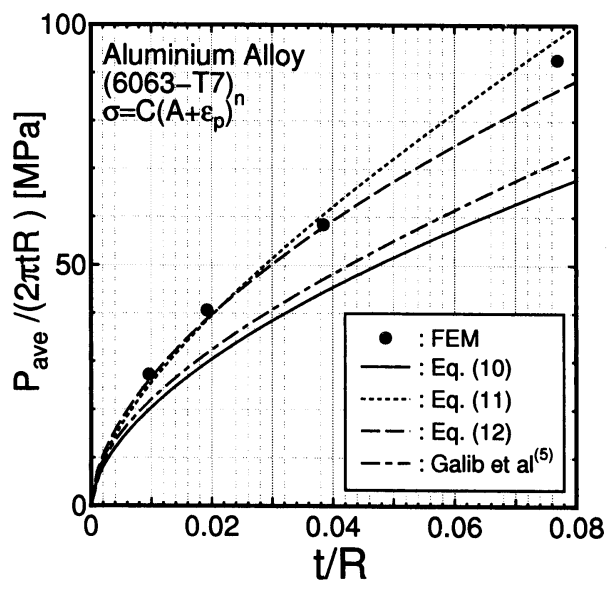

Fig. 12 Relationship between Average Stress $P_{\text {ave }} /(2 \pi t R)$ and Tube Thickness-to-Radius Ratio $t / R$ for Tubes of Aluminium Alloy 6063-T7

3.2.3 実験値と近似値との比較ささらに, 本研究 で提案した平均応力に対する近似評価法の有効性を確 かめるため, 実際の衝撃吸収部材を軸方向へ準静的に 圧潰する実験を行った。ここで用いた吸収部材は，端 部に取り付け用のフランジを有するアルミニウム合金 （5052-H112）製の薄肉円筒であり，その形状を図 13 中 に示す. 図 13 は円筒の外径 $D_{\text {out }}=54[\mathrm{~mm}]$ と $60[\mathrm{~mm}]$ での軸方向圧縮荷重 $P_{x}$ と圧潰変位 $U_{x}$ との関係を表す. 
Table 1 Comparison of Average Load $P_{\text {ave }}$ between Experimental Results and Approximations from Eqs.(11) and (12) for Some Values of Outer Diameter $D_{\text {out }}$

\begin{tabular}{c|c|c|c|c}
\hline$D_{\text {out }}[\mathrm{mm}]$ & 54 & 56 & 58 & 60 \\
\hline$P_{\text {ave,experiment }}[\mathrm{kN}]$ & 35.65 & 70.36 & 117.9 & 170.0 \\
\hline Equation (11) $[\mathrm{kN}]$ & 41.36 & 82.64 & 136.0 & 204.5 \\
(Error) \% & $(16.0)$ & $(17.5)$ & $(15.4)$ & $(20.3)$ \\
\hline Equation (12) [kN] & 36.85 & 69.79 & 109.9 & 159.0 \\
(Error) \% & $(3.37)$ & $(0.81)$ & $(6.79)$ & $(6.47)$ \\
\hline
\end{tabular}

図中には式 (11), (12) を用いて求めた平均荷重 $P_{\text {ave }}$ の 近似結果もそれぞれ点線と破線で示している．また， 表 1 は外径 $D_{\text {out }}$ を 4 種類 $(54,56,58,60[\mathrm{~mm}])$ 変えたと きの, 実験で得た平均荷重 $P_{\text {ave,experiment }}$ と近似式 (11), (12)による結果を比較したものである. 表 1 中の括弧 内の值は, 実験結果と各近似結果との相対誤差の絶対 値を示す. 表 1 の結果からもわかるように, 円筒に生 じるしわの生成過程も考慮した近似式 (12) による結 果と実験結果との相対誤差は, 外径 $D_{\text {out }}$ の大小に関 わらず $10 \%$ 以内にとどまっており，このことから本 研究で提案した近似手法は工学的な評価として十分有 効であるといえる.

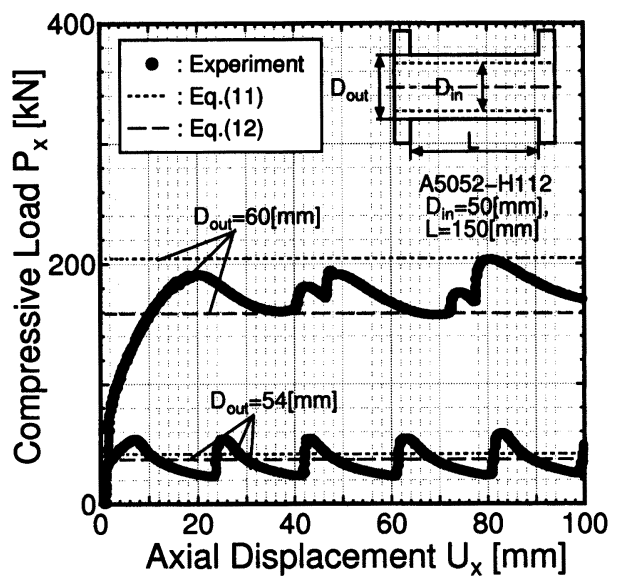

Fig. 13 Comparison of Experimental Result and Approximate Value of Average Stress $P_{\text {ave }} /(2 \pi t R)$ for a Cylindrical Tube of Aluminium Alloy $5052-\mathrm{H} 112$

\section{4. 結}

本研究では, 円筒の軸圧潰における平均荷重 $P_{a v e} に$ ついて, 有限要素法による弾塑性数值シミュレーショ ン解析を行い, 平均荷重 $P_{\text {ave }}$ に及ぼす加工硬化の影響 を検討した. 解析結果により以下の結論が得られた.

(1) 加工硬化が非常に小さい場合, 本数値解析結果は, 円筒に生じるしわの曲率を考慮した剛完全塑性体 での理論解とほぼ一致する.

（2）加工硬化が大きいほど, 平均荷重 $P_{a v e}$ の值は増加 するため,これまで提案された剛完全塑性体での 理論解をそのまま用いて平均応力 $P_{\text {ave }} /(2 \pi t R)$ を 正しく評価できない.

（3）加工硬化を考慮した平均荷重の評価を行うため, 剛完全塑性体での理論解中の降伏応力 $\sigma_{y}$ の代わ りに, 1 つのしわ内部に生じる相当塑性ひずみの 平均值 $\bar{\varepsilon}_{p, e q}$ を利用して定義した流れ応力 $\sigma_{f l o w}$ を 用いることで，二直線硬化則や $n$ 乗硬化則に従う 円筒においても，精度よく評価することができる。

（4）本研究で提案した平均荷重に対する近似結果は, 実際の衝撃吸収部材として用いられるアルミ合金 製薄肉円筒の準静的圧潰実験結果と $10 \%$ 以内の 範囲で一致し,このことからも本手法が工学的に 十分有効なものであるといえる.

\section{文献}

(1) Alexander, J.M., An Approximate Analysis of the Collapse of Thin Cylindrical Shells under Axial Loading, Quarterly Journal of Mechanics and Applied Mathematics, 13-1(1960), pp.10-15.

(2) Abramowicz, W. and Jones N., Dynamic Axial Crushing of Circular Tubes, International Journal of Impact Engineering, 2-3(1984), pp.263-281.

(3) Wierzbicki,T. et al., Alexander Revisited-A Two Folding Elements Model of Progressive Crushing of Tubes, International Journal of Solids and Structures, 29. 24(1992), pp.3289-3295.

(4) Ushijima, K. et al., Evaluation of First Peak Stress in Axial Collapse of Circular Cylindrical Shell, Transactions of the Japan Society of Mechanical Engineers, Series A, Vol.70, No.700(2004), pp.1695-1702.

(5) Al Galib, D. and Linam, A., Experimental and Numerical Investigation of Static and Dynamic Axial Crushing of Circular Aluminium Tubes, Thin-Walled Structures, No.42(2004), pp.1103-1137.

(6) Murase, K. and Jones, N., Experiments on the Dynamic Axial Plastic Buckling of Circular Tubes, Journal of the Society of Materials Science, Japan, Vol.42, No.483(1993), pp.1420-1426.

(7) Sogo, T. et al., Analysis of Energy Absorption Abilities of Thin-Walled Tubes by Impact Axial Crushing, Transactions of the Japan Society of Mechanical Engineers, Series A, Vol.63, No.605(1997), pp.146-151. 
(8) Sasaki, K. and Kurokawa T., Axisymmetric Collapse of Circular Tube due to Impact and its Parametric Study for Shock Absorber, Transactions of the Japan Society of Mechanical Engineers, Series A, Vol.63, No.616(1997), pp.2610-2617.

(9) Fujiwara, T. and Hasimura T., Design Considerations Concerning Axial Collapse Characteristics of Circular Tubes, Transactions of the Japan Society of Mechanical Engineers, Series A, Vol.64, No.620(1998), pp.10691076.

(10) Yamasaki, K. et al., A Study on Maximization of Dynamic Crushing Energy Absorption of Cylindrical Shell Structures, Transactions of the Japan Society of Mechanical Engineers, Series A, Vol.64, No.620(1998), pp.1077-1083.

(11) Tanimura, S. et al., Dynamic Axial Crushing Test to Thin-Walled Circular Tube Specimen and Evaluation of Its Energy Absorption Ability, Transactions of the Japan Society of Mechanical Engineers, Series A, Vol.65, No.635(1999), pp.1622-1628.

(12) Tanimura, S. et al., A Study on Dynamic Progressive Buckling of Steel Circular Tubes, Transactions of the Japan Society of Mechanical Engineers, Series A, Vol.66, No.642(2000), pp.382-389.

(13) Alghamdi, A.A.A., Collapsible Impact Energy Absorbers: an Overview, Thin-Walled Structures, No.39(2001), pp.189-213.

(14) Guillow, S.R. et al., Quasi-Static Axial Compression of Thin-Walled Circular Aluminium Tubes, International Journal of Mechanical Sciences, No.43(2001), pp.21032123.

(15) Bardi, F.C. et al., On the Axisymmetric Progressive Crushing of Circular Tubes under Axial Compression, International Journal of Solids and Structures, No.40(2003), pp.3137-3155.

(16) Abbas, H. et al., Curved Fold Model Analysis for Axi-Symmetric Axial Crushing of Tubes, Thin-Walled Structures, No.41(2003), pp.639-661.

(17) Matsuda, T. et al., Effect of Crush Speed to Deformation Mode for Cylindrical Shells under Compression, Proceedings of the 42th Hokuriku-Shinetsu Branch Regular Meeting of the Japan Society of Mechanical Engineers, No.047-01(2005), pp.47-48.

(18) Ushijima, K. et al., Strain Concentration for Cylindrical Tubes subjected to Axial Compression, Transactions of the Japan Society of Mechanical Engineers, Series A, Vol.71, No.707(2005), pp.1023-1029. 